\title{
MATING SEASON AND COLONY FOUNDATION OF THE SEED-HAR VESTER ANT, VEROMESSOR PERGANDEI
}

\section{By Gregory B. Pollock ${ }^{1,2}$ and Steven W. Rissing 1,3}

The seed harvester ant Veromessor pergandei is common in most of the Mohave Desert and xeric portions of the Sonoran Desert of the United States and Mexico (Creighton 1950). Throughout extensive portions of its range it is sympatric with ecologically similar Pogonomyrmex spp. (Cole 1968, Wheeler and Wheeler 1973, Davidson 1977a, Rissing 1981). Hypotheses to explain coexistence of these species include use of different foraging temperatures (Bernstein 1974), foraging methods (Davidson 1977b), preferred forage item size (Davidson 1977a), and method of predator avoidance (Rissing 1981). While information is available regarding reproductive behavior and colony structure of Pogonomyrmex spp. (Hölldobler 1976a, Markl et al. 1977, MacKay 1981, Davidson 1982), comparison with $V$. pergandei is precluded by lack of information for the latter. Accordingly, we have observed mating season and colony foundation of $V$. pergandei.

\section{Materials ANd Methods}

Previous observations of $V$. pergandei in central Arizona indicated mating flights occur in late Winter/early Spring at midmorning, under clear skies as air temperatures reach approximately $22^{\circ} \mathrm{C}$. Five $V$. pergandei colonies on an undeveloped section of the desert Botanical Garden, Phoenix, Arizona, were selected for observation of flight activity during this period. The 10 ha study area is native Sonoran Desert with Larrea tridentata, Carnegia gigantea and Prosopis velutina predominant woody plants. All nests were observed daily from 28 January to 20 March 1984 unless it was overcast, during which time all nests were completely inactive. Each morning an observer visited each nest and counted total number of alates

\footnotetext{
'As equal contributors.

2School of Social Science, University of California, Irvine, California 92717

3Department of Zoology, Arizona State University, Tempe, Arizona, 85287

Manuscript received by' the editor October 25, 1984
} 
flying from the nest during a 2 min. period. Observations continued until above ground activity ceased or reduced to only "nest work", with no further sighting of alates. Fewer than 10 alates flying from a nest per min. was regarded as "low intensity" flight activity while $\geqslant 10$ alates per min. was regarded as "high intensity" flight activity.

We observed colony foundation at several sites in South Mountain Park, Phoenix, Arizona. The habitat at South Mountain is similar to that at the Botanical Garden (the two areas are $17 \mathrm{~km}$ apart) but includes several sandy ravines not found at the latter. These ravines attract founding queens which are easily collected or excavated. In 1983 we made as complete a sample as possible of all founding nests along one of the ravines at South Mountain. This survey occurred late in the flight season (in mid-March) when most females were expected to have flown and established nests.

A similar survey of founding nests was conducted in a second ravine in 1984 to chart the course of colony foundation throughout the flight season. Approximately every other day (and every day that flight activity was observed at the Botanical Garden) the ravine was surveyed and all founding nests collected. Care was taken to examine apparently preferred nest establishment sites, e.g. under flat rocks, boards and other such objects. Sixty-one of the queens collected during these 1984 surveys were dissected to determine mating success throughout the flight season.

During the first half of the 1984 mating season we also partially excavated adult $V$. pergandei nests and collected all alates found. Samples were counted according to sex, dried and weighed individually.

\section{RESULTS}

Mating season of $V$. pergandei was almost 2 months long (Fig. 1). While there was some coordination of flight activity between nests (e.g. 7 March, Fig. 1), on numerous days only one colony released alates, e.g. nest $\mathrm{Vp}-1$ (lowest histogram in Fig. 1) released alates on 11 days when no other observed nest did so. Most of the days during which no flight activity occurred appeared too cold, overcast or windy for flights. As a proximal cue, even light wind appeared sufficient to preclude flight. We frequently observed alates gather at the nest entrance and then run into the nest in apparent response to breezes or stronger gusts. 


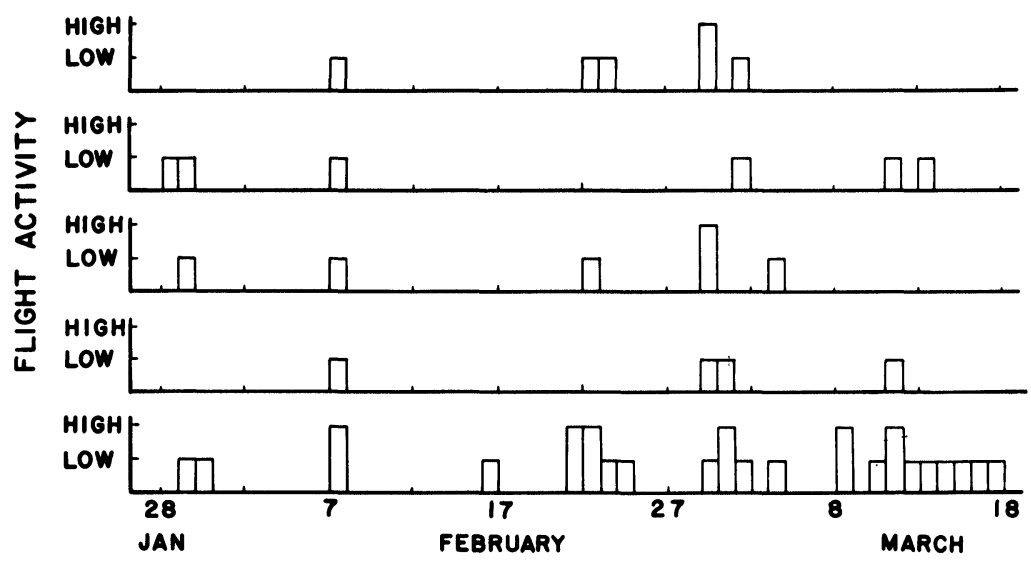

Figure 1. Flight activity of five $V$. pergandei colonies at the Desert Botanical Garden, Phoenix, AZ, January - March 1984. "Low intensity" flights are those where $<10$ alates flew from the nest per min.; "high intensity" flights had $\geqslant 10$ alates fly per min.

During observation of flights it was usually not possible to accurately sex individuals leaving the nest. Nonetheless, two cases of unusual sex ratios were noted. One colony discovered at the Botanical Garden in February 1983 was obviously very young, as indicated by the single, small crater and nest entrance as well as the small size of its workers. This colony produced no alates during 1983 and produced only female alates during 1984 . Additionally, nest Vp-1 produced only males during the last 7 days of the mating season; an increasing proportion of these males were unable to fly correctly as the season progressed.

Of eight adult colonies partially excavated to determine alate sex ratio, six exhibited a strong bias toward reproductive investment in females; the remaining two colonies produced only males. For those colonies with female alates, the average ratio of reproductive investment ( $\mathrm{mg}$ females:mg males) was 9.7 (Table 1 ).

All but five of the $61 \mathrm{~V}$. pergandei queens dissected were inseminated suggesting females mate throughout the long flight season. The five uninseminated queens appear randomly distributed with respect to probable flight date, collection locale, and number of cofoundresses. 
Veromessor pergandei is strongly pleometrotic; $89.1 \%$ of all queens found in 1983 came from multiple queen associations (Fig. 2). Formation of associations is not density-dependent. Percentage of all queens found pleometrotic during regular surveys of ravines in 1984 is uncorrelated with queen density for that survey $(r=-.058$; $\mathbf{N}=9$ days when more than one queen was found).

While searching for foundress associations we regularly found dealate queens in a group under rocks or similar objects in an immobile, "pupoid" state (i.e. legs and head held tightly under the thorax as seen in ant pupae). "Pupoid" queens were usually found when environmental conditions, especially soil temperature, were conducive to $V$. pergandei activity as indicated by simultaneous foraging of nearby adult colonies. Exact function of "pupoid" behavior, following flight and mating but preceeding excavation, is unclear but may promote accumulation of queens into a developing pleometrotic association. There appears a clear cost of predation associated with any such behavior that delays excavation of a burrow. We frequently observed up to $50 \%$ of the starting nests in an area destroyed (either by a rodent or lizard); additionally, we observed predation on foundresses at or near the soil surface by centipedes, spiders and fire ants (Solenopsis sp.).

\section{Discussion}

The mating season of $V$. pergandei is quite long when compared with sympatric seed-harvester species. For example, Pogonomyrmex spp. have a brief mating season determined by summer rains; colonies release all alates during one or several days of flight activity (Hölldobler 1976a, Markl et al. 1977, Davidson 1982). By comparison, $V$. pergandei releases alates over a $2 \mathrm{mo}$. period; frequently a colony releases only a small number of alates for many days (Fig. 1). Method of colony foundation also differs dramatically between $V$. pergandei and Pogonomyrmex spp. While $V$. pergandei frequently forms foundress associations (Fig. 2), Pogonomyrmex rugosus rarely does so. Of 70 starting $P$. rugosus colonies excavated in Tempe, AZ, 66 contained a single queen (Rissing and Pollock, unpublished data). Similarly, Höldobler (1976b) reports that "hundreds" of founding $P$. rugosus, $P$. barbatus and $P$. maricopa colonies contained only a single queen. 
Table 1. Reproductive investment of Veromessor pergandei colonies according to sex.'

\begin{tabular}{|c|c|c|c|c|c|}
\hline $\begin{array}{c}\text { Collection } \\
\text { Date } \\
1984 \\
\end{array}$ & $\begin{array}{c}\text { No. } \\
\text { Al.ATES }\end{array}$ & $\begin{array}{c}\% \\
\text { MALE: }\end{array}$ & $\begin{array}{c}\text { MEAN MASS } \\
\text { OF MALES } \\
\text { mg } \\
(\mathrm{N} ; \mathrm{SD}) \\
\end{array}$ & $\begin{array}{c}\text { MEAN MASs } \\
\text { OF FEMAlES } \\
\text { mg } \\
(\mathrm{N} ; \mathrm{SD}) \\
\end{array}$ & $\begin{array}{c}\text { INVESTMENT } \\
\text { RATIO) } \\
\mathrm{mg}: \mathrm{mg} \\
\end{array}$ \\
\hline 29 January & 201 & 17.4 & $\begin{array}{c}5.666 \\
(33 ; 0.432)\end{array}$ & $\begin{array}{c}19.686 \\
(129 ; 1.333)\end{array}$ & 16.5 \\
\hline 3 February & 104 & 100.0 & $\begin{array}{c}6.378 \\
(87 ; 0.407)\end{array}$ & 0.0 & \\
\hline 3 February & 122 & 27.0 & $\begin{array}{c}6.231 \\
(31 ; 0.417)\end{array}$ & $\begin{array}{c}20.536 \\
(66 ; 1.090)\end{array}$ & 8.9 \\
\hline 3 February & 110 & 10.0 & $\begin{array}{c}7.086 \\
(11 ; 0.388)\end{array}$ & $\begin{array}{c}20.560 \\
(77 ; 1.060)\end{array}$ & 26.1 \\
\hline 6 February & 169 & 33.1 & $\begin{array}{c}5.812 \\
(49 ; 0.498)\end{array}$ & $\begin{array}{c}19.953 \\
(93 ; 0.942)\end{array}$ & 6.9 \\
\hline 7 February & 486 & 30.0 & $\begin{array}{c}5.724 \\
(110 ; 0.466)\end{array}$ & $\begin{array}{c}19.098 \\
(164 ; 1.190)\end{array}$ & 7.8 \\
\hline 26 February & 335 & 26.0 & $\begin{array}{c}5.859 \\
(69 ; 0.428)\end{array}$ & $\begin{array}{c}20.576 \\
(151 ; 0.870)\end{array}$ & 10.0 \\
\hline 26 February & 90 & 100.0 & $\begin{array}{c}5.671 \\
(85 ; 0.408)\end{array}$ & 0.0 & \\
\hline
\end{tabular}

'Only colonies from which more than 50 alates were collected are reported.

Veromessor pergandei seems similar to the honey ant Myrmecocystus mimicus in its founding behavior. Both species form pleometrotic nests (Fig. 2; Wheeler 1917, Bartz and Hölldobler 1982); natal nests of both species are also clumped. Bartz and Hölldobler (1982) suggest that clumping of $M$. mimicus natal nests is due to avoidance of adult conspecific colonies by at least some founding queens, for adult colonies destroy any conspecific colonies they find (Hölldobler 1981, Bartz and Hölldobler 1982). Hence local queen density rises in those areas lacking an adult colony, increasing both the probability of pleometrosis and local density of natal nests. Our observations suggest a different mechanism must exist for $V$. pergandei, for here queen density is uncorrelated with pleometrosis. Further, natal nests do not avoid areas near adult colonies. This is noteworthy, for we have seen foraging columns of adult $V$. pergandei colonies destroy natal nests. Nonetheless, natal nests were regularly found within the foraging radius of an adult colony; often all queens found after a flight were within such a radius. 


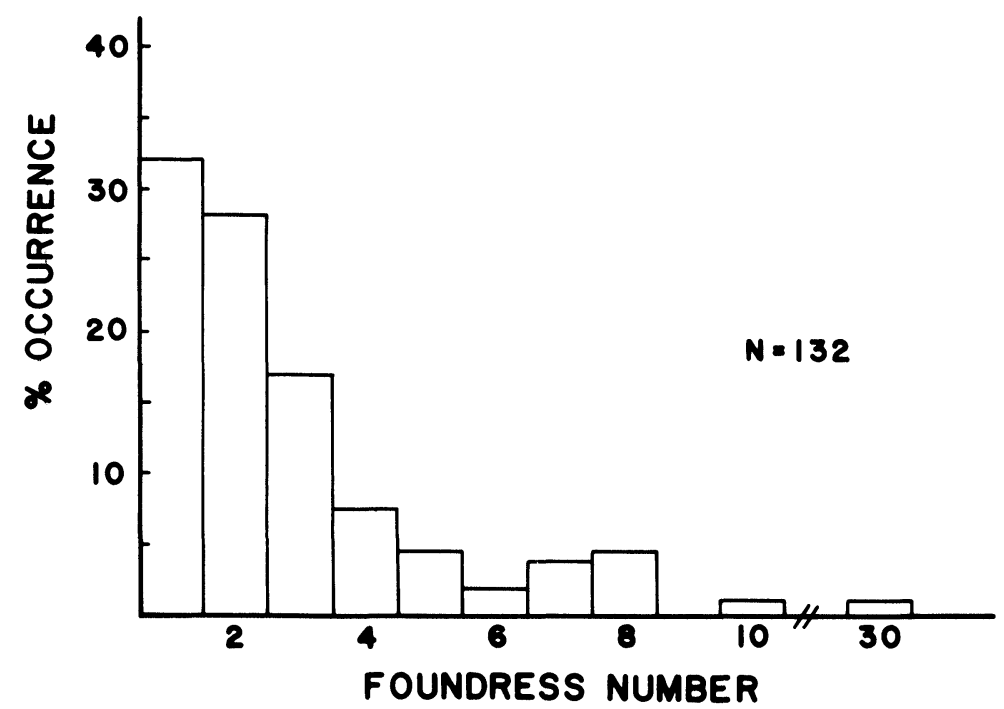

Figure 2. Pleometrosis in V. pergandei natal nests collected at South Mountain Park March 1983.

Among other primary pleometrotic ant species, queen density is correlated with average number of cofoundresses/nest ( $M$. mimicus: Bartz and Hölldobler 1982; Solenopsis invicta: Tschinkel and Howard 1983). Queens seem predisposed to cofound and readily join conspecific queens when encountered. Under high queen density the probability of such encounter is high, insuring pleometrosis. High queen densities are common in M. mimicus and $S$. invicta, for adult colonies release alates synchronously during the flight season. Adult $V$. pergandei colonies, however, release alates (often asynchronously; Fig. 1) over a lengthy period. In 1984 queen density after any flight was low; pleometrosis was nonetheless common. Queens seemed attracted to sites relatively protected from predators, e.g., under flat rocks or boards, rather than avoidant of adult conspecific colonies. We believe $V$. pergandei's flight season precludes pleometrosis through random association under high queen density.

Although the exact mechanism generating pleometrosis remains unclear, we have evidence that $V$. pergandei's mating system is 
involved. We have searched for $V$. pergandei mating sites during the last $3 \mathrm{yr}$ without success. Several observations, however, suggest such sites are small, local and on or near the ground. We have found horned lizard (Phrynosoma sp.) fecal pellets consisting soley of $V$. pergandei alate exoskeletons at South Mountain. Absence of workers in these fecal pellets suggests alates were not consumed at the nest site, where workers would have vigorously mobbed any horned lizard (Rissing 1981). We have also noticed starting colonies are clumped along ravines at South Mountain even when queen density is low. Live males occur frequently in these clumps, under debris within $1 \mathrm{~m}$ of starting nests or actually associated with one or several females. These observations, along with the high percentage of fertilized females found throughout the protracted mating season, suggest mating occurs on or near the ground in small, localized groups. These observations also suggest males and females do not differentially disperse after mating; this is unusual among insects (Thornhill and Alcock 1983).

Another line of evidence supports this view of $V$. pergandei's mating system. If alates mate in small, localized groups, males do not compete panmitically for females. Such limited alate dispersal should select for female biased ratios of investment among parental colonies (Hamilton 1967, Bulmer and Taylor 1980, Taylor and Bulmer 1980, Charnov 1982, Wilson 1983). All of the colonies we have excavated had such a bias or contained only males (Table 1). This investment pattern cannot be explained through worker control of sex ratio, for observed biases were three times as large as those predicted under worker control (Trivers and Hare 1976, Benford 1978, Oster and Wilson 1978, Charnov 1982). If our sampling method is an adequate measure of a colony's partitioning of sexual investment, this is strong evidence that $V$. pergandei alates exhibit. low dispersal with respect to their parental colony-mates. This is what we would expect when colonies release alates asynchronously over a lengthy period.

Veromessor pergandei is sympatric with several Pogonomyrmex spp. throughout its range and occurs exclusively in more xeric areas of the Mohave Desert (Creighton 1950, Wheeler and Wheeler 1973, Rissing 1981). If our analysis of $V$. pergandei's mating system is correct, it offers a strong contrast to that of Pogonomyrmex spp. Pogonomyrmex produce a few massive mating aggregations ("leks"), 
incorporating alates from many colonies, with females later dispersing to form haplometrotic nests (Chapman 1957; Nagel and Rettenmeyer 1973; Hölldobler 1976a, b; Davidson 1982). Veromessor pergandei, however, seems to produce many local, small mating aggregations, both temporally and spatially apart, where females fail to disperse after mating but actively form pleometrotic nests. Such differences may provide insight into the distribution and abundance of $V$. pergandei relative to Pogonomyrmex spp.

\section{SUMMARY}

Veromessor pergandei, a seed-harvester ant common to the Mohave and portions of the Sonoran Desert, has a mating season lasting almost 2 months. Colonies release small numbers of alates on warm, cloudless and windless days from January to March in Phoenix, AZ. Release of alates from one colony often occurs without similar releases from nearby colonies. Dealate queens captured throughout the mating season are, nonetheless, usually inseminated. Veromessor pergandei usually initiates colonies through pleometrosis; $89 \%$ of all queens collected in 1983 were pleometrotic. Several lines of evidence suggest males and females do not differentially disperse after mating; this failure to disperse from the mating aggregation may help induce pleometrosis in this species. Colonies of $V$. pergandei produce 9.7 times more $\mathrm{mg}$ of female alates than male alates on average. Length and timing of mating season and initial colony structure of $V$. pergandei differ dramatically from that of ecologically similar and sympatric Pogonomyrmex spp.; such differences may provide insight into the distribution of this species relative to Pogonomyrmex spp.

\section{ACKNOWLEDGEMENTS}

The Desert Botanical Garden and its personnel granted permission to use their undeveloped habitat and provided enthusiastic support. J. C. Bald win assisted in field surveys; ant dissections were performed by P. F. Ankney. B. Hölldobler provided useful comments on an earlier draft. This work has been supported by an Arizona State University Faculty Grant-in-aid and National Science Foundation Grant DEB-8207052 (SWR, principal investigator). 


\section{Lithrature Citho}

BARTZ, S. H. AND B. Höll.DOBLER.

1982. Colony founding in Myrmecocystus mimicus Wheeler (Hymenoptera: Formicidae) and the evolution of foundress associations. Behav. Ecol. Sociobiol. 10:137-147.

BINFORD, F.

1978. Fisher's theory of the sex ratio applied to the social Hymenoptera. J. Theor. Biol. 72:701-727.

Bernstein, R. A.

1974. Seasonal food abundance and foraging activity in some desert ants. Amer. Natur. 108:490-498.

Bulimer, M. G. and P. D. TAYlor.

1980. Dispersal and the sex ratio. Nature. 284:448-449.

Chapman, J. A.

1957. A further consideration of summit ant swarms. Canadian Entomol. 89:389-395.

Cuarnov, E. L.

1982. The Theory of Sex Allocation. Princeton University Press. Princeton, New Jersey.

Col.e, A. C.

1968. Pogonomyrmex harvester ants. University of Tennessee Press, Knoxville, Tennessee.

Craiginton, M. W.

1950. The ants of North America. Bull. Mus. Comp. Zool. 104:1-585.

Davidson, D. W.

1977a. Species diversity and community organization in desert seed-eating ants. Ecology 58:711-724.

1977b. Foraging ecology and community organization in desert seed-eating ants. Ecology 58:725-737.

1982. Sexual selection in harvester ants (Hymenoptera: Formicidae: Pogonom!rmex). Behav. Ecol. Sciobiol. 10:245-250.

HAMII.TON, W. D.

1967. Extraordinary sex ratios. Science. 156:477-488.

HöLLLDOBILR, B.

1976a. The behavioral ecology of mating in harvester ants (Hymenoptera: Formicidae: Pogonomyrmex). Behav. Ecol. Sociobiol. 1:405-423.

1976b. Recruitment behavior, home range orientation and territoriality in harvester ants, Pogonomyrmex. Behav. Ecol. Sociobiol. 1:3-44.

MACKAY, W. P.

1981. A comparison of the nest phenologies of three species of Pogonomyrmex harvester ants (Hymenoptera: Formicidae). Psyche 88:25-47.

MARKI, H., B. HöLLLDOBLER AND T. HölLDOBLER

1977. Mating behavior and sound production in harvester ants (Pogonomyrmex, Formicidae). Ins. Soc. 24:191-212. 
Nagel, H. G. and C. W. Rettenmeyer.

1973. Nuptial flights, reproductive behavior and colony founding of the western harvester ant, Pogonomyrmex oc'cidentalis (Hymenoptera:Formicidae). J. Kansas Entomol. Soc. 45:82-101.

Oster, G. F. AND E. O. WiLson.

1978. Caste and Ecology in the Social Insects. Princeton University Press. Princeton, New Jersey.

Rissing, S. W.

1981. Prey preferences in the desert horned lizard: influence of prey foraging methods and aggressive behavior. Ecology 62:1031-1040.

TAYIOR, P. D. AND M. G. Bullmer.

1980. Local mate competition and the sex ratio. J. Theor. Biol. 86:409-419.

THORNHILl, R. AND J. Aico('K.

1983. The Evolution of Insect Mating Systems. Harvard University Press, Cambridge, Mass.

TRIVERS, R. L. AND H. HARE

1976. Haplodiploidy and the evolution of the social insects. Science. 191:249-263.

WHEFLleR, G. C. AND J. WheELER.

1973. Ants of Deep Canyon. University of California, Riverside.

WHEELER, W. M.

1917. The pleometrosis of Mirmecocystus. Psyche 104:180-182.

WII.SON, D. S.

1983. The group selection controversy: history and current status. Ann. Rev. Ecol. Syst. 14:159-187. 

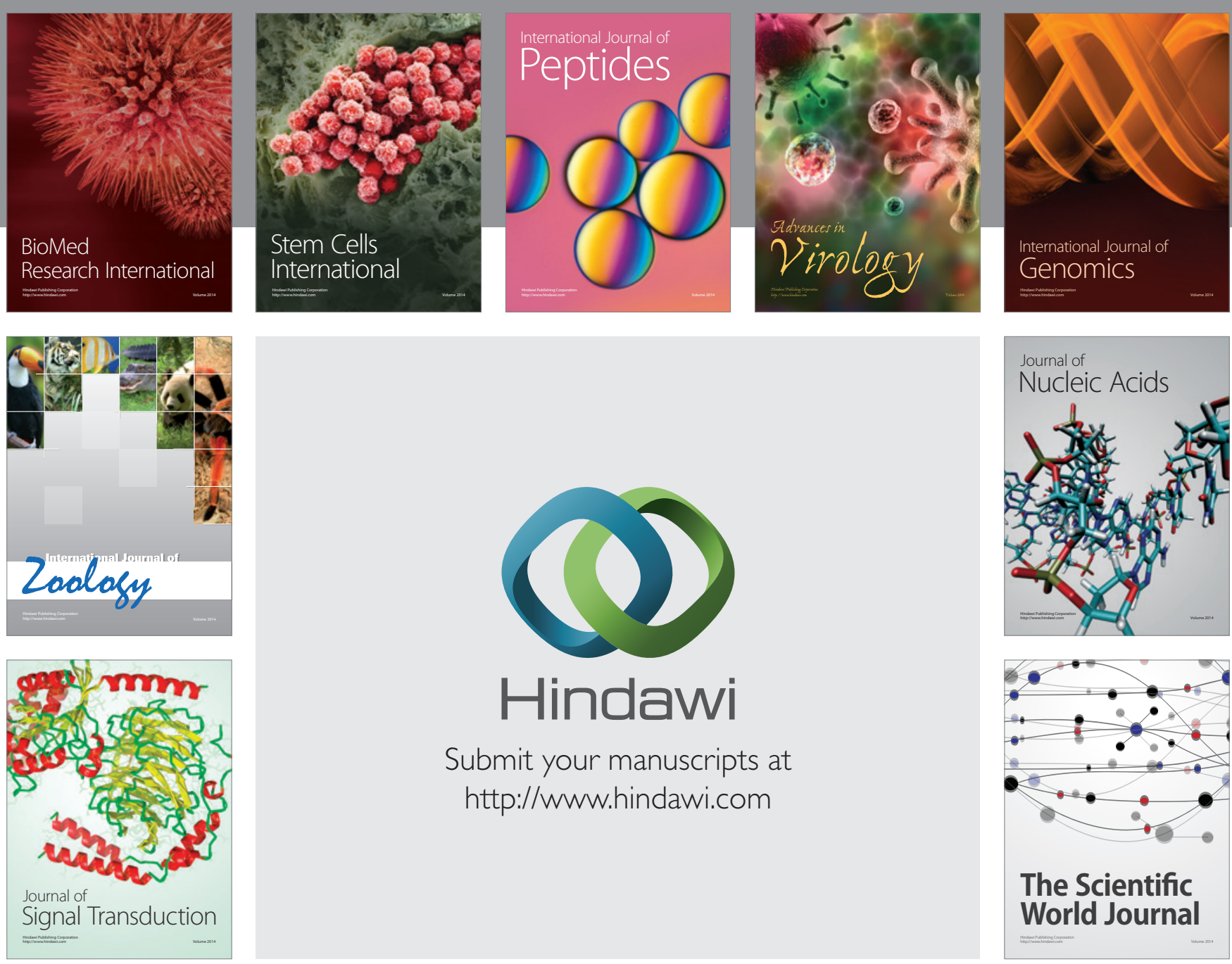

Submit your manuscripts at

http://www.hindawi.com
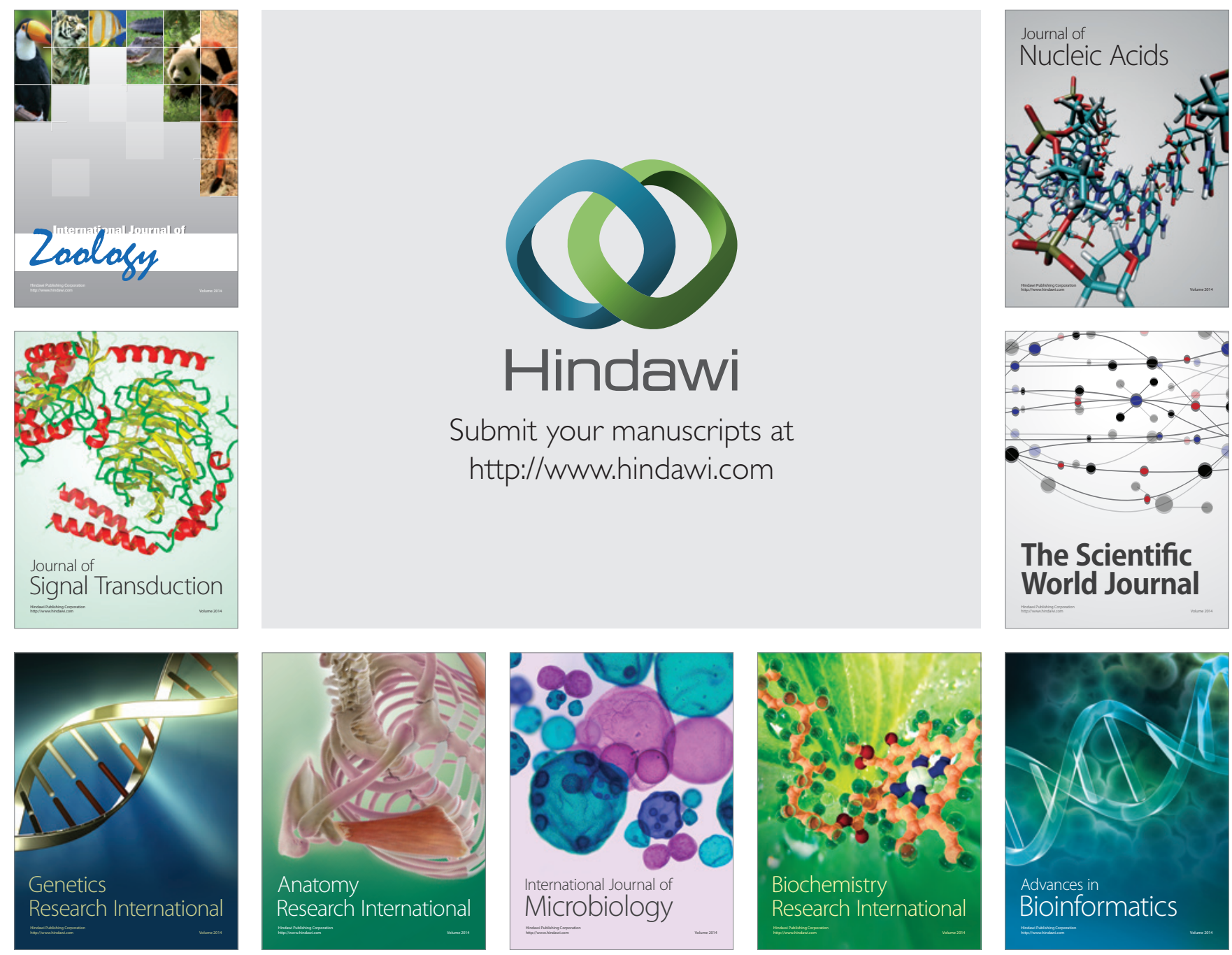

The Scientific World Journal
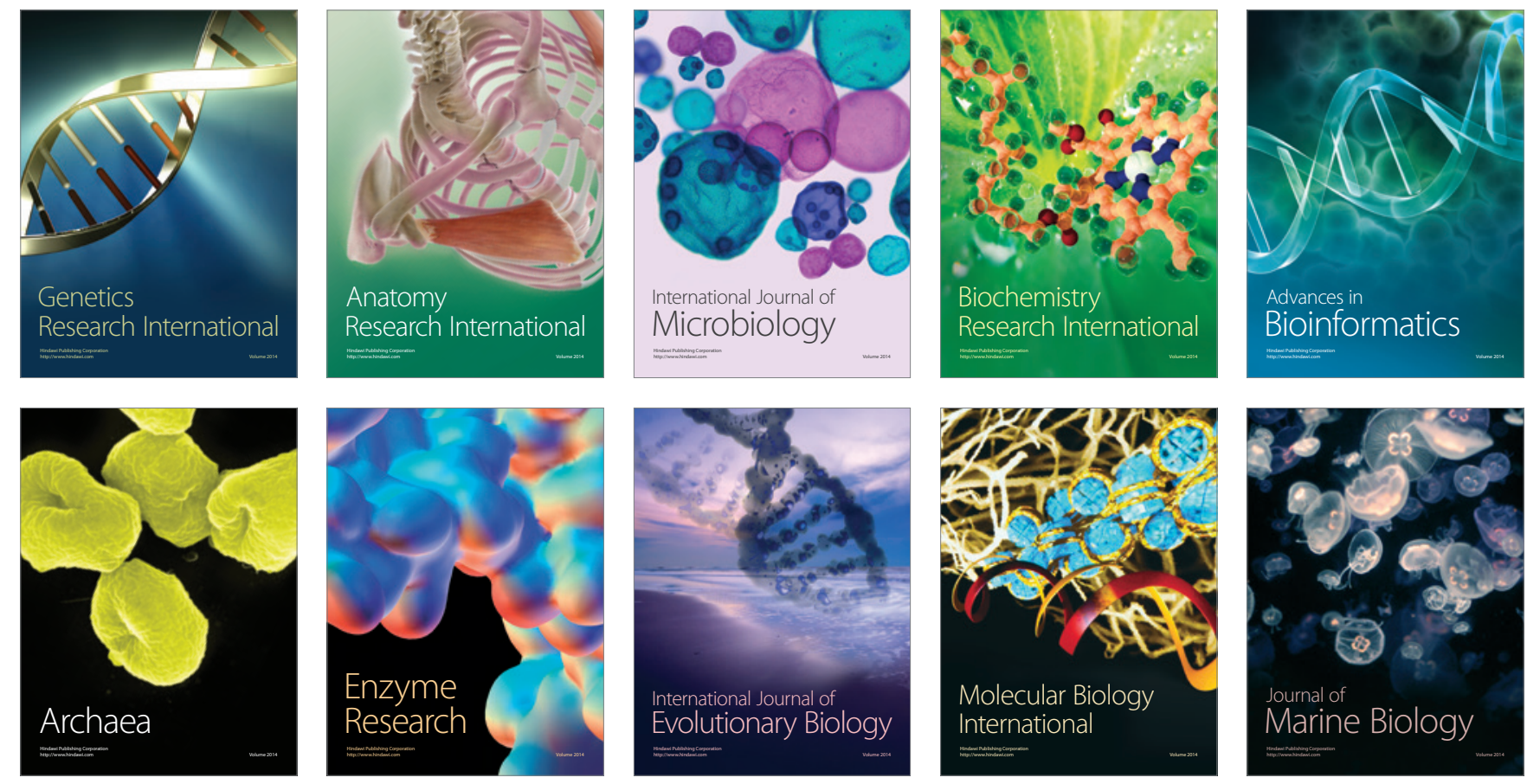